\title{
Are migrants an asset in recession? Insights from Italy
}

\section{Alessandra Venturini}

University of Torino, Italy, MPC,IZA

Department of Economics, Lungo Dora Siena 100, Torino, Italy

Tel +39 011 6704044, ORCiD: 0000-0001-8858-2743

alessandra.venturini@unito.it

\section{Claudia Villosio}

Collegio Carlo Alberto, LABOR, Turin, Italy

Via Real Collegio 30, 10024 Moncalieri (TO), Italy

Tel +39 011 6705063, ORCiD: 0000-0002-1709-4395

Corresponding author:

Alessandra Venturini

alessandra.venturini@unito.it

The authors gratefully acknowledge helpful comments and suggestions by the editors and the reviewers. Claudia Villosio also lle lly acknowledges Compagnia di San Paolo and the University of Torino for financial support through Grant “progetti di Ateneo/CSP - Anno 2014 - Addressing H2020”.

No potential conflict of interest is reported by the authors.

Manuscript size: $8.140 \underline{8.281}$ words 


\title{
Are migrants an asset in recession? Insights from Italy
}

\begin{abstract}
In this paper we analyse the characteristics of employed migrants before and after the beginning of the recession in Italy to understand whether the economic crisis has exacerbated or reduced the high segmentation of the Italian labour market, with foreign workers largely concentrated in low-paid and low-quality jobs, even when highly educated.

The analysis looks separately at male and female migrants because of strong gender specialization, with the female component highly concentrated in the homecare and healthcare sectors, and the male component mainly employed in the manufacturing and construction sectors.

We inquire how employment, working conditions and wages have changed before and after the crisis in the sectors and occupations where foreign workers are concentrated with respect to the other sectors and occupations of the Italian economy. We conclude that the disadvantage of being in a segmented labour market nevertheless allowed for positive growth of foreign employment during the recession, but it implied an even greater segregation in terms of low-skilled, unstable, and poorly paid jobs.
\end{abstract}

Keywords: migration, Italy, economic crisis, segmentation, labour market integration 


\section{Introduction}

Recession may represent an opportunity for a country and its economy to choose the future growth path. On one hand adverse economic situations may stimulate innovation, investment and productivity growth (Paserman 2013, Kahanec and Zimmermann 2016). This is the case in which firms, facing hard competitive pressure decide to implement innovative technologies, to invest in highly skilled production, and in workers' human capital growth (Schumpeter 1934). Or in contrast firms may react to stronger pressure by a status quo-oriented strategy (Lewis, 2011). In this case the economy will maintain investments in the same type of production and sectors by reducing costs and human capital involvement. In the first case the demand for highly skilled labour will increase, while in the second case the labour demand will grow for even more low-skilled workers. The demand for foreign labour will thus be different according to the different model prevailing in the country. In the first case firms will search for highly skilled migrants to invest in innovation, in the second one, firms will look for low-skilled migrants to maintain the low-skilled production.

In Europe the scenario is very diversified. The United Kingdom has been successful in pursuing the strategy of attracting highly skilled migrants, while Germany has been less so (OECD 2014a). Conversely, Southern European countries appear to be following the status quo-oriented strategy and are experiencing more outflows of highly skilled foreign workers than inflows (OECD 2014a).

On the supply side, economic global recessions, by changing the pull and push factors, modify migration streams. Historically migration studies have shown how emigration is negatively related to unemployment at the destination (pull) and positively related to unemployment at the source (push). In periods of recession changes in inflows and increases in returns home are expected (Trenz and Triandafylidou 2016). However, Papademetriou et al. (2010), suggest that return migration flows could increase in periods of recession but that they are more affected by developments in the country of origin and the ease of circulation than by economic conditions in destination countries. In addition Reyneri (2009) and Strom, Venturini, and Villosio (2013) 
highlight how returns flow can be determined by both failures and success. In fact, migrants may decide to return if the migration project fails or, in the opposite case, if the migration project is highly successful and allows them to continue their economic activity at home (Koser 2009). Hatton and Williamson (2009) point out that when economic conditions deteriorate in the destination countries and restrictions of inflows are implemented, migration flows change their channel of entrance. The use of the family reunification channel increases, while the use of the labour channel of entrance decreases, affecting the composition of the foreign labour supply.

The economic crisis is thus expected to increase the return of migrants facing low journey costs and having the possibility of going back and forth easily; while in the presence of high costs of migration and low portability of social benefits, migrants may increase settlement and family reunifications processes. As a consequence, the stock of migrants may not decrease even in the presence of a reduction of labour inflows, whereas the composition of the migrant labour will change.

Against this background, Italy represents an interesting case to analyse. Similar to what happens in the other Southern European countries, Italy presents a segmented labour market, where foreign workers are largely concentrated in low-skilled and low-paid jobs, even when highly educated. However, unlike what has been observed elsewhere, the growth of immigration in Italy did not stop during the years of the crisis. The growth of foreign employment although lower than the pre-2008 values, continued to be positive during the years after 2008 and even when the GDP growth rate turned negative. Such dynamics represent a distinct feature in the European scenario and particularly among Southern European countries where foreign employment dropped significantly.

In this paper we want to understand whether the segmentation of the Italian labour market and the concentration of migrants in low-wage occupations and in fragile sectors has increased migrants’ economic vulnerability or instead represented a secure harbour during the great recession 
shocks given the Southern European model of integration described by Ponzo and Finotelli in the introduction.

We used different waves of the Italian labour force survey (Eurostat) to analyse the labour market status and performance of immigrants workers before and after the beginning of the economic recession with the aim of understanding how job opportunities for foreign workers have evolved and, in particular, to understand whether the economic crisis has exacerbated or reduced the high segmentation of migrants in the Italian labour market.

A comparison between the native and foreign employment and unemployment dynamics has been undertaken, as well as an analysis of the segmentation by sector and occupation, and of wages.

This study looks, separately, at male and female migrants given the strong gender specialization, with females highly concentrated in the homecare and healthcare sectors, and the male component mainly employed in the manufacturing and construction sectors. By analysing the characteristics and the dynamic of the occupations in which immigrants are clustered, the paper proposes an enriched and novel perspective on the jobs held by immigrants and on the dynamics of migrant labour segmentation over recent years.

The remainder of the paper proceeds as follows. Section 2 provides background information on the Italian labour market model and the role of foreign employment. Section 3 describe the recent evolution on migration inflows and highlights the changes in channel of entrance, country of origin, and gender balance. It also details the labour market segmentation of foreign workers by proposing and discussing an analysis by occupations. Section 4 analyses the impact of the economic crisis on the immigrant segregation, focusing on job quality characteristics and wages. Section 5 offers concluding observations.

\section{Immigrants in the Italian labour market}

During the 1970s. Italy moved from being a sender country to becoming a host country, receiving 
immigrants largely from developing countries and Eastern Europe. This process continued in the following decades with remarkably high annual growth rates of the immigrant population. According to OECD (2014b) Italy is among the OECD countries that have experienced the largest inflows of immigrants since 2000 both as absolute levels and as a percentage of the resident population. By 2014, foreign migrants represented $8.9 \%$ of the population and $12 \%$ of the total workforce; $60 \%$ of them were located in the North, $25 \%$ in the Centre, and only $15 \%$ in the South (ISTAT 2014).

Even before the arrival of immigrants, the Italian economy presented a large segmentation with a primary labour market - the public administration and the large firms - where workers are offered better wages and working conditions obtained by strong trade union involvement, and a secondary market - made of small firms and low-skilled jobs in the agriculture, manufacturing, construction, family and care services - with lower levels of pay, poor working conditions and insecure employment (Dolado 2016, Christofides, Polycarpou, and Vrachimis 2013, Goos, Manning, and Salomons 2009, Olivetti and Petrongolo 2008, Bettio et al. 2012).

The characteristic of the inflows of immigrants who, in the majority, were regularized after arriving illegally- and thus were not selected before arrival - created what has been called a “subordinate integration”, resulting in high labour market segmentation along ethnic lines, occupational segregation of immigrants in the lowest layers, and very low occupational and social mobility (Ambrosini 2001).

Initially migration consisted of low-skilled male migrants - though in a few cases they had higher qualifications - employed in agriculture, construction, and manufacturing and a few female migrants employed predominantly in the family services sector as a response to the shortage of national labour force for those types of jobs given the working conditions (Ambrosini 2001). During the 1990s, more and more immigrants began to be employed as blue collar workers in northern firms. Manufacturing rapidly became the prevailing sector for regular inclusion. The excess demand of Italian firms, in particular small firms in the North-East, for low-skilled workers 
could be filled by immigrants who were more flexible and adaptable to poor working conditions and low wages than native ones (Del Boca and Venturini 2005). As agreed almost unanimously in academic debate (to cite just a few: Ambrosini 2001, Reyneri and Fullin 2008, Gavosto, Venturini, and Villosio 1999, Venturini and Villosio 2006), immigrants in Italy have always been complementary to nationals rather than a substitute. Immigrants in Italy were necessary to satisfy the need for low-skilled labour in construction, manufacturing, domestic services, and care, which was unmet by local workers (Reyneri 2004). Furthermore Dell’Aringa, Lucifora, and Pagani (2015) find that immigrant workers face a "glass-ceiling" that prevents them from accessing high-paying occupations. Immigrants, in fact do not benefit from returns to human capital in terms of access to better paid occupations; rather their returns in human capital are limited to an intra-occupational earnings progression ${ }^{1}$. Strom, Venturini, and Villosio (2013) show that the segregation of migrants into low-skilled jobs has a long-lasting feature. The majority of foreign workers in fact spend their entire working career in these jobs without moving to a different one.

The existing strong segmentation and the strict complementarity between natives and migrants explains how it has been possible for Italy to have massive immigration flows that have not been accompanied by economic growth during the same period. In fact the growth of the foreign population has involved limited economic and social costs, or even benefits, for many of the actors involved in the phenomenon. On the one hand native workers' labour market prospects in terms of wages and employment have not been negatively affected by the massive inflows of immigrant workers (Gavosto, Venturini, and Villosio 1999, Venturini and Villosio 2006, Staffolani

\footnotetext{
${ }^{1}$ The authors also highlight that this result contrasts with the empirical evidence provided for other countries. For instance, Chiswick and Miller (2009) show that for the United States education is the key factor determining access to high-paying occupations for immigrants when compared to natives.
} 
and Valentini 2010), and, on the other hand, low-cost foreign labour has allowed firms and economic sectors to survive the growing international competition (Murat and Paba 2003)².

By using 2005 Italian data from the Eurostat labour force survey, we provide a snapshot of both the sector and occupation segmentation of foreign workers before the recession. This represents the departure point of our analysis. Information on nationality is used as the criteria to differentiate foreigners from natives. Foreigners holding a EU 15 nationality are however excluded as they are not the focus of the empirical analysis. It is worth noting that the populations of immigrant and foreigner largely overlap in the Italian case, but not completely. In fact foreigners include also individuals who are born in Italy but do not have Italian citizenship.

Table 1 and Table 2 show that in Italy before the great recession there were two levels of segmentation, the first along sectors of employment: male foreign workers were concentrated in the manufacturing and construction sectors and female workers in personal and household services, manufacturing, and hotel and restaurants (see Table 1). In addition there was also segmentation in the occupations held by immigrants-foreigners employed in these sectors (Table 2): few occupations were in fact characterized by having both a large incidence (share of foreign workers versus natives workers) and a large concentration (share of foreigners in a given occupation versus the total foreign employment) of foreign workers.

The next sections further explore the characteristics of such segmentation and the impact the economic crisis has had on it.

INSERT Table 1 and table 2 about here

\section{Recent dynamics: the impact of the crisis on the Italian migration model}

\subsection{Changes in the structural characteristics of the supply of migrants}

Economic downturns led to a substantial transformation in migration flows which may affect the

\footnotetext{
${ }^{2}$ This model has also been described by Pastore, Salis, and Villosio (2013) as a "low-cost immigration model”.
} 
structural characteristics of the migrant population (Bertoli, Brücker, and Fernández-Huertas Moraga. 2016). In fact admission policies in destination countries may be subject to change in an attempt to regulate immigration inflows. At the same time, in origin countries, the prevailing pull and push factors are altered by the global deterioration of economic prospects. The combination of these two trends modifies both the channels of entrance in the destination country and the characteristics of migration streams across Europe, affecting, in turn, the options of migrants' employment. In the Italian setting, the most important structural characteristics of foreign employment affected by the economic crisis concern the country of origin of migrant flows and the channel of entrance.

With regard to the first aspect, data on how the composition of the foreign working population by country of origin has evolved in recent years helps explain the roles played by geographic distance and the mobility regime in shaping migration flows during the crisis (Table 3).

At present foreign workers from New Member States and other Eastern and Central European countries represent $60 \%$ of total foreign employment (51\% among males and 66\% among females) (see Table 3); the percentage was 47\% in 2005 (43\% among males and 52\% among females). This increase took place at the expense of the African component which in fact declined from $32 \%$ in 2005 to $21 \%$ in 2013 for male foreign employment and from $15 \%$ to $7 \%$ for female. The importance of the Asian and Latin American component remained relatively stable in the period.

The free mobility regime for citizens of the new EU member countries ${ }^{3}$, by eliminating restrictions on returning home and re-returning to the host country, reduces the cost of migration and alleviates many consequences of the crisis (Kahanec et al. 2009). When economic prospects in destination countries decrease, migration projects are more likely to fail and thus the cost of migration tends to increase, particularly for the longer distance migrants and those who face mobility restrictions to moving back and forth. This, among other arguments, explains why

\footnotetext{
${ }^{3}$ Internal EU mobility is also perceived as very limited compared to its potential; see Recchi 2015.
} 
migration flows from Eastern EU countries (see Cvajner and Sciortino 2009) have continued even after the economic crisis, while flows from other countries have declined or increased at a much lower pace ${ }^{4}$. The analysis of the evolution of the African component throughout the 2005-2013 period (table 3) shows that its declining importance among foreign employment had in fact already started at the beginning of the twenty-first century, and it has only intensified with the economic crisis. This tendency, which is similar to that observed in other countries such as Spain, has also been facilitated by the prevailing visa policy of EU member states, relatively open to Eastern European countries, and relatively strict for African and poor Asian countries (Finotelli and Sciortino 2013). This asymmetric visa regime combined with the increase in the cost of migration due to the deterioration of labour market conditions in destination countries, are the key drivers of the reduction in the African migration flows which dominated foreign inflows during the 1990s and early 2000s.

\section{INSERT Table 3 about here}

Concerning the channel of entrance, a picture of the transformation taking place is provided by data on residence permits for Italy. Unfortunately they refer only to third country nationals who are the only one who need to follow this legal procedure to enter Italy.

Table 4 shows that during the recession years, a change in the channel of entrance has indeed taken place. Beginning in 2011 residence permits for work reasons have registered a dramatic drop, while those for family reunifications have remained stable. As a consequence, more than half of residence permits issued in 2013 to migrant women and 30\% of permits issued to migrant men are for family reason; permits issued for work purposes are $23 \%$ for female and $42 \%$ for male. Taking male and female residence permits together, those for family reunification purposes overcome those for labour reasons ${ }^{5}$.

\footnotetext{
${ }^{4}$ For an update analysis of intra-European migrations see Salamonska and Recchi 2016

${ }^{5}$ The same has happened in Spain.
} 
The change in the entrance channel of migration flows is relevant in order to understand the dynamics within foreign employment. In fact, coming from the same family background, the new flows of migrants are more likely to enter employment in the same occupation and sectors of employment as their family members who have already settled, or in the jobs prevailing in their community of reference, reinforcing network effects of the migration chain already present. As an example, in the Filippino case, both husbands and wives tend to be in the family sector; in the case of Romanians, men are concentrated in the construction sector and women in the family sector or sales. This persistence brings no substantial change to the composition by type of job of the foreign labour force, thus contributing to perpetuating the status quo.

\section{INSERT Table 4 about here}

A third significant structural change in the supply of migrants in Italy is the recent process of feminization of the foreign working population, with the male/female employment gap moving from more than 40\% in 2005 to less than 20\% in 2013 (Italian Labour Force data, Eurostat). This trend has two main causes. On one hand there is a constantly expanding wave of family reunifications as witnessed by the increasing number of resident permits for family reasons (Table 4). On the other hand the most recent years have seen a substantial increase in the phenomenon of female migrants originating from the Eastern European countries, often first-movers, driven by the home- and healthcare sectors. Their high human capital and habit of working hard make them highly flexible and ready to accept any job available (Marchetti and Venturini 2013).

\subsection{Foreign and native employment and unemployment dynamic}

During the decade preceding the current economic crisis Italy experienced a tremendous increase in its foreign population, with annual growth rates around 15\%. However, unlike what was observed elsewhere, the growth of immigration in Italy did not stop even in the crisis years (see Figure 1). Importantly, even labour migration, which, of all types of migration, is expected to be affected most by the crisis, did not register a significant drop. 
As highlighted by Figure 1, which compares the Italian trend to other Southern and Northern European countries, the pace of growth of all foreign employment in Italy declined from its pre2008 levels, but it continued to be positive and higher than the GDP growth rate, even when this started to be negative.

\section{INSERT Figure 1 about here}

Such a dynamic represents a distinct feature of the Italian situation within the European scenario. In fact a very different dynamic has been observed in the Continental countries - France and Germany - where the negative GDP growth rate corresponded to a negative foreign employment growth. As shown by the first two panels of Figure 1, the drop in foreign employment mirrored the drop in GDP in France, and with a lag in Germany, however, in both countries the foreign labour market effect of the crisis has been significant.

The different pattern observed in Italy is not unexpected because France and Germany have different foreign employment characteristics with respect to the Southern European ones. Nevertheless the Italian experience also contrasted with the dynamic of the other Southern European countries. Starting in 2008, Portugal, Spain, and Greece in fact, experienced a dramatic drop in foreign employment growth, which became and remained negative in all of the subsequent years. In Italy foreign employment growth maintained positive values in all of the observed period.

A comparison of trends in employment rates of foreigners and Italian nationals (Figure 2a) shows that foreign male and foreign female employment rates are always higher than the national ones before and throughout the post-2008 period. The foreign male employment rate has been very sensitive to the economic cycle and has declined more rapidly than the native male one, from 83\% in the 2006 has converged on 70\% which is the corresponding national one. However, a positive gap in favour of foreigner employment rate still persists also in the recent years. On the female side, employment rates do not appear to be significantly affected by the economic downturn. This is mainly related to the different gender specializations: female foreigners are in fact highly 
concentrated in the homecare and healthcare sectors, which have been less affected by the economic crisis than the manufacturing and construction sectors where the male component is concentrated.

Although foreign employment has continued to grow in absolute value, the capacity of the Italian labour market to absorb the flows of foreign job seekers with the same intensity as before has been severely reduced by the crisis. While before the recession the foreign male unemployment rate was similar to natives', beginning in 2009, the male foreign unemployment rate has skyrocketed, passing from 5\% to 17\%, while the unemployment rate of Italian males increased has as well but remains below 12\%. Again, female foreigners started from a much higher unemployment rate than men 15\%, in 2005 and 12\% in 2008, and reached $18 \%$ in the most recent years. Although starting from a higher level, the increase in the female unemployment rate is lower than the corresponding male one. Female immigrants seem to be more resilient in terms of their employment than men (Figure 2b).

INSERT Figure 2 about here

\subsection{Segmentation across sectors}

As anticipated above, one of the key explanations for how it was possible to combine no GNP growth with continuous positive foreign employment growth lies in the specific Italian labour market integration model and particularly in the existing polarization in the economic structure of the Italian economy which has attracted and retained only low-skilled migrant workers .

Table 1 points out the different sector concentrations of foreigners and natives. For males in 2005 54\% of the natives are just in three sectors - manufacturing; trade; and financial, business and other services - while $66 \%$ of the European migrants from the new accession countries are employed in just two sectors - manufacturing and construction. Third national males are as well strongly concentrated in manufacturing (32\%) and construction (24\%) but are also present in the trade and hotels sectors. Eight years later, in 2013, no particular changes are detected for male natives, with the exception of a reinforcement of the services sector, while for foreigners we find a 
shift from manufacturing and construction (sectors that were severely hit by the economic crisis) towards trade and hotels and restaurants ${ }^{6}$.

For female workers the polarization is even stronger: in $200546 \%$ of third country foreigners and $42 \%$ of new member state nationals are concentrated in the household sector, while $25 \%$ of native women are in health and education, and trade (16\%). After the crisis, polarization among female foreign workers is even stronger with almost half of them working in the household sector. In 2013 48.9\% of third country nationals and 44.1\% of new member state foreigners are employed in personal and household services.

\subsection{Segmentation across occupations}

The strong segmentation affecting foreign workers can be even better appreciated when looking at occupations.

LFS data for Italy show that the incidence of foreign workers has a large variability across occupations $^{7}$. There are occupations where foreigners are largely represented and others where their presence is equal to zero.

A deeper look into the employment of natives and foreigners by occupation clearly shows that there are a number of occupations which alone absorb more than half of foreign workers. This happens for both male and female foreign workers, but it is particularly evident among foreign women. The list of these occupation is shown in Table $2^{8}$. The distinguishing feature of these

\footnotetext{
${ }^{6}$ Due to a major revision of the classification of economic activity that has affected data collected from year 2008 onwards, the distributions in 2005 and 2013 are not fully comparable and some misalignments may occur. Data not shown but available upon request

${ }^{7}$ Occupations are identified according to the Isco88 (data up to 2009) and Isco08 (data form 2010 onwards) classification at three-digit level.

${ }^{8}$ Occupations have been selected on the Isco88 classification according to the largest share of foreign employment over employment in each occupation and of foreign employment over total foreign employment at three-digit level in 2008. For male the occupations selected and the corresponding ISCO codes are: Construction workers (Isco88= 931 and 71); Machine operators and assemblers (Isco88=
} 
occupations is that they have both high incidence of foreign employment (the share of foreign employment is more than double the average share in the economy), and they employ a large number of foreign workers, i.e. there is a large concentration of foreign employment. For simplicity, we label these occupations as "migrant occupations (MigOcc)”. This polarization has been described by Zanfrini (2015) in terms of migrants being concentrated in “ethnicized” jobs, protected by symbolical barriers from the entrance of indigenous workers.

In 2005 about 54\% of male and 61\% of female foreign employment was in the MigOcc jobs; the incidence of foreign workers on total employment in these occupations was $14 \%$ for male and 21\% for female. Considering that on average in Italy in 2005 foreign employment accounted for about $5 \%$ for male and $4.5 \%$ for female on total employment, the incidence of foreign labour in migrant occupations was quite large especially for females.

\section{What is the impact of the crisis on segmentation?}

\subsection{Trends in polarization}

Existing studies for Italy have already analysed immigrants’ outcome in terms of employment and unemployment during the economic crisis (Bonifazi and Marini 2013, Paggiaro 2013). Our focus here is to understand how labour market polarization has evolved during the crisis years and how migrants’ vulnerability has been affected by it.

Table 5 shows that while more than half of the male foreigners were employed in MigOcc before the start of the crisis, the same was true for less than $20 \%$ of the male natives. For women the

82 and 932); Domestic workers (Isco88=913); Street vendors (Isco88=911); Transport workers (isco88=933); and Agricultural workers (Isco88=921). For females they are: Domestic workers (Isco88=913); Housekeeping and restaurant service workers (Isco88= 512); Personal care and related workers (Isco88= 513); and Building cleaners (Isco88= 714). From 2010 on, Eurostat LFS data make use of the Isco08 classification of occupations. Data on occupation for this period have been selected according to the corresponding table provided. Data are largely comparable before and after the change in the ISCO classifications; however the issue of comparability across the two ISCO classifications cannot be completely ruled out and be should kept in mind while interpreting the data. 
polarization was even worse. The share of foreign women employed in MigOcc was nearly six times higher than the native share. Eight years later, the picture changed differently for men and women. For men, as a result of the economic recession, the concentration of foreign labour in MigOcc slightly decreased, but this has not reduced the incidence of foreign workers in these occupations. On the contrary, it has increased and is more than twice as high as the average (26\% with respect to an average incidence of foreign male employment in the Italian economy of $10 \%$ ).

This is the result of trends that have affected the "migrant" and "non-migrant" occupations differently, and the native and foreign workers, as Table 5 shows (bottom panel). Foreign male employment in MigOcc increased at a similar pace as the growth in other occupations up until the crisis, and has slowed, with respect to both the pre-crisis period and the other occupations, since 2008. However, native employment in the migrant occupations has shown markedly negative growth $(-25 \%)$ in the crisis years and it was already negative in the pre-crisis period. Consequently, the incidence of male foreign labour in such occupations has significantly and constantly risen up to $26 \%$ in 2013.

For foreign women, polarization in MigOcc has also increased substantially during the crisis years. Therefore in 2013 these occupations represent the employment solution for a large majority of female migrants (70\%). Whereas these occupations also experienced an increase in native female employment, the incidence of foreign workers in such occupations has increased from the already large $21 \%$ in the pre-crisis period, to $35 \%$ in the post-crisis period.

Female and male foreign employment has also increased in the other occupations but this increase is not sufficient to reduce the concentration of immigrants in the specific MigOcc occupations.

INSERT Table 5 about here 


\subsection{Polarization and working conditions}

This increasing polarization could be brought about by the low and decreasing human capital of more recent migration flows, but Table 6, which shows some job characteristics, indicated that this is not the case. The share of low educated foreigners has not increased, nor in MigOcc or in general $^{9}$. For both male and female foreigners the number of hours worked has declined. This is a broad trend which affects occupations in general, however among MigOcc the reduction in hours worked is more pronounced. Similarly, the incidence of part-time employment has increased particularly in migrant occupations, and for foreign males employed in MigOcc, temporary employment has also increased.

What thus emerges from this analysis is that working conditions in "ethnicized” jobs have deteriorated more than average as a consequence of the crisis, further exacerbating the traditional weaknesses of the Italian migration model, which is unable to fully exploit the migrants' potential.

INSERT Table 6 about here

\subsection{Polarization and wages}

To complete the picture of the effect of the crisis on polarization we turn to a multivariate analysis of the wage information present in Eurostat LFS data. Since 2009, Italian LFS data report for each worker the individual's position in the national distribution of take-home wages. This variable is grouped into 10 classes deriving from the decile of the wage distribution and can be considered as an aggregate measure of the return of human capital, the investment in the job, and job seniority. Although it is not possible to have a complete picture from before and after the crisis, this variable allows us some interesting insights into the wage dynamics in migrant occupations.

\footnotetext{
${ }^{9}$ A comparison with natives shows that the share of the low educated in MigOcc is lower among foreigners than natives by 11 points among males and 20 points among females, confirming, the over-qualification of migrants in the Italian labour market.
} 
We estimate separate probit models by year and gender on the probability of being in the bottom part of the wage distribution (having a monthly wage level equal or below the third decile) ${ }^{10}$. Thus, our dependent variable measures the probability of being in a low-paid job, taking into account the gender specificity in job segregation. The key independent variables included in the models are based on the interaction between the native/foreign nationality and being or not employed in migrants’ occupations as defined above. We therefore have four cases: natives in nonmigrant occupations (reference category), natives in migrant occupations, foreigners in non-migrant occupations, and foreigners in migrant occupations.

Additional individual controls include age (10 age classes), marital status (married, single, widowed, or divorced), education level (three classes: no school, primary, and lower secondary; upper secondary; tertiary), sector of economic activity (20 classes according to the NACE 1-digit classification), geographical region.

To allow comparability of the results across years they are presented as average marginal effects (AMEs). Figure 3 reports the results of the exercise. It shows AMEs for the variables of interest: natives in migrant occupations and foreigners in migrant and non-migrant occupations. They can be read as the change in the probability of being in the bottom part of the wage distribution for workers belonging to one of the three categories with respect to being a native in non-migrant occupations (benchmark). For instance, in 2009, male foreigners employed in MigOcc, had a $14 \%$ higher likelihood of being low paid with respect to national workers in non-migrant occupations. Similarly, this probability is equal to $11 \%$ for male foreigners in non-MigOcc, and $7 \%$ for nationals in MigOcc. In 2013 the same probabilities are respectively 17\%, 13\%, and 6\%. Clearly, for foreign men the recession has worsened their conditions in terms of wages, not only with respect to natives employed in occupations with a low incidence of foreign labour, but also with respect to natives employed in “ethnicized jobs”. In fact, while the low-paid penalty for natives in these jobs has decreased, it has increased for both groups of male foreigners. Although less

\footnotetext{
${ }^{10}$ This analysis is similar to Dustmann and Frattini (2011) which however refers to year 2009 only.
} 
educated than migrants, native workers in MigOcc have been able to reach comparatively higher wages, confirming once more how the consequences of the crisis in terms of deterioration of the quality of jobs have been mostly borne by immigrants.

Turning to foreign women, the situation appears quite different. First, foreign women in migrant occupations are clearly penalized with respect to native women in non-ethinicized occupation, however they are not so different in terms of the low-wage penalty from natives in migrant occupations. Furthermore the recession appears to have further reduced the distance between foreigners and native women in ethnicized jobs. Second, wages of (the few) migrant women in non-migrant occupations are slowing converging towards native women’s wages, although in 2013 female foreigners still have a 9\% higher probability of being low paid with respect to their native counterparts. Third, the already marked distance between the number of female foreigners employed in the two groups of occupations (ethnicized/not-ethnicized) has further increased during the recession years.

INSERT Figure 3 about here

To get deeper insights into the issue, we further distinguish immigrants between new member states and third country nationals because the different rule of entrance may affect their labour market performance.

What emerge from Table 7 is that among males, foreigners coming from non-EU countries face a higher likelihood of being low paid than citizens of new member states, in both migrant and non-migrant occupations. The economic downturn has however increased the low-wage penalty in both immigrant groups.

Among female foreigners, no substantial differences are detected in the ethnicized jobs, with new member states and third country migrants facing the same probability of being low paid. Greater differences between the two groups emerge in the non-migrant occupations. Here, at the beginning of the recession period, new member state female migrants, recently migrated and likely 
to accept any job, had a higher low-wage penalty than third country female migrants. In 2013, with an increased period of settlement of new member state workers, the situation is reversed with third country nationals being more heavily penalized.

\section{INSERT Table 7 about here5. Conclusion}

The research has shown that the recession was a lost opportunity for the Italian economy to start a deep restructuring of the economic processes and upgrading the skill content of the production and the labour force. Italy has a labour force concentrated in small and medium-sized firms, with a high concentration of employment in low- and medium-skilled jobs. This creates a demand for immigrant labour in the low-skilled occupations in agriculture, construction, trade, and family services. The strong segmentation of foreign employment in the Italian labour market is even more evident when analysing the occupations where migrants are employed. This paper has shown that foreign workers are concentrated in a few "ethnicized jobs" with almost no chance of mobility out of these occupations. The long-lasting economic recession has reinforced the low-skill production model of the Italian economy and has led to a degradation of immigrants' employment opportunities: increased polarization of foreigners, particularly females, in "Migrant occupations”, deterioration of the quality of their employment (in terms of precariousness and low pay), in parallel with an increase of unemployed migrants. The crisis has thus exacerbated the general situation of foreign employment, increasing their high segregation in specific low-quality sectors and jobs, with no career upgrading and widespread over-qualification.

The crisis had, however, different impacts across gender. Male foreign employment was hit harder by the crisis in quantitative terms because male immigrants are particularly concentrated in sectors that are very sensitive to the economic cycle (construction and manufacturing). However, native workers employed in the same sectors have suffered more from the recession and have lost their jobs at a higher rate than migrants, who increased their importance in such jobs during the 
crisis. If male foreign workers were moderately protected from the quantity side, the same cannot be said on the quality side, which has undergone a general deterioration in terms of longer hours, higher precariousness and lower pay, as a probable consequence of firms’ strategy of labour costs contraction.

For migrant women, the demand for labour expressed by families to cover jobs in the care sector typically deserted by Italians has led to an increase of the foreign presence in these occupations which currently absorb around $70 \%$ of the female foreign labour force. Job demand in this sector is strongly connected with the aging of the population and the type of welfare model which relies on the family as the main provider of care services to children, elderly, disabled, and other needy people. The demand for these services was little affected by the crisis, also because care jobs have limited appeal for the native population due to high constraints in terms of the long hours of work and their personal freedom.

The Italian economic model based on small businesses and traditional sectors has not been transformed by the crisis, and Italy still resorts to foreign labour because of its characteristic adaptability to low-skilled jobs and difficult working conditions. If on the one hand this model, thanks to the demand for migrant intensive jobs, has allowed foreign employment to be partially protected from the effects of the crisis, on the other hand it has increased migrants' risk of ending up in even more precarious work situations.

The future of this economic model is questionable. On the female employment side, the aging of the population will increase the share of older people in need of care services. For example the share of the $75+$ over the $20-70$ year old population is $12 \%$ in 2015 and in 2050 is projected to grow to $25 \%$. The constraint in the fiscal budget, aggravated by the economic downturn, will not allow an expansion of the national welfare system, forcing Italian households to still resort on care services provided by migrant women. At the same time, the increase in native female labour market participation will further raise the demand for care services. All of these will maintain and probably even increase the demand of foreign labour but will also increase the risk for migrant women to 
remain trapped in these jobs with no prospect of upgrading and exploiting their potential human capital.

The situation is quite different on the male employment side where competition with production taking place in developing countries at much lower costs could reduce any profit margin and push non-innovative firms to shut down their production, reducing migrants’ opportunities in the sectors where they are traditionally concentrated. 
Table 1 Foreign and native employment by sectors in 2005

\begin{tabular}{lrrr|rrr}
\hline & \multicolumn{3}{c|}{ MALE } & \multicolumn{3}{c}{ FEMALE } \\
\hline & Natives & $\begin{array}{r}\text { New } \\
\text { member } \\
\text { states }\end{array}$ & $\begin{array}{r}\text { Third } \\
\text { country } \\
\text { nationals }\end{array}$ & $\begin{array}{r}\text { New } \\
\text { member } \\
\text { states }\end{array}$ & $\begin{array}{r}\text { Third } \\
\text { country } \\
\text { nationals }\end{array}$ \\
\hline Agriculture & $4.7 \%$ & $5.2 \%$ & $6.0 \%$ & $3.3 \%$ & $2.9 \%$ & $2.1 \%$ \\
Manufacturing & $\mathbf{2 5 . 9 \%}$ & $\mathbf{2 9 . 1 \%}$ & $\mathbf{3 2 . 0 \%}$ & $\mathbf{1 6 . 3 \%}$ & $\mathbf{1 6 . 5 \%}$ & $\mathbf{1 3 . 3 \%}$ \\
Construction & $12.5 \%$ & $\mathbf{3 7 . 1 \%}$ & $\mathbf{2 3 . 5 \%}$ & $1.2 \%$ & $2.8 \%$ & $0.6 \%$ \\
Trade & $\mathbf{1 5 . 3 \%}$ & $6.2 \%$ & $10.9 \%$ & $\mathbf{1 5 . 8 \%}$ & $9.2 \%$ & $5.6 \%$ \\
Hotels and restaurants & $3.7 \%$ & $2.5 \%$ & $7.0 \%$ & $5.7 \%$ & $\mathbf{1 4 . 1 \%}$ & $\mathbf{1 1 . 3 \%}$ \\
Transport & $7.0 \%$ & $6.4 \%$ & $6.1 \%$ & $3.3 \%$ & $1.4 \%$ & $1.0 \%$ \\
Financial, business, and other services & $\mathbf{1 2 . 5 \%}$ & $4.8 \%$ & $5.7 \%$ & $15.4 \%$ & $5.4 \%$ & $11.7 \%$ \\
Public administration & $7.4 \%$ & $0.0 \%$ & $0.1 \%$ & $5.6 \%$ & $0.6 \%$ & $0.1 \%$ \\
Education \& health & $7.0 \%$ & $2.5 \%$ & $0.8 \%$ & $\mathbf{2 5 . 4 \%}$ & $5.5 \%$ & $8.5 \%$ \\
Personal and household services & $3.8 \%$ & $6.3 \%$ & $7.7 \%$ & $8.0 \%$ & $\mathbf{4 1 . 5 \%}$ & $\mathbf{4 5 . 8 \%}$ \\
Total sample size (in thousands) & 12890 & 96 & 615 & 8359 & 103 & 343 \\
\hline Source: Om
\end{tabular}

Source: Our elaboration on Eurostat Italian LFS.

Table 2 Foreign employment by occupations in 2005.

\begin{tabular}{|c|c|c|}
\hline & $\begin{array}{r}\text { Share of foreign } \\
\text { employment over } \\
\text { total employment in } \\
\text { the occupation in } \\
2005 \text { (Incidence) }\end{array}$ & $\begin{array}{r}\text { Share of foreign } \\
\text { employment over } \\
\text { total foreign } \\
\text { employment in } 2005 \\
\text { (Concentration) }\end{array}$ \\
\hline \multicolumn{3}{|l|}{ Male } \\
\hline Construction workers & $11.9 \%$ & $26.7 \%$ \\
\hline Machine operators and assemblers & $11.7 \%$ & $12.3 \%$ \\
\hline Domestic workers & $48.6 \%$ & $5.6 \%$ \\
\hline Street vendors & $19.5 \%$ & $2.8 \%$ \\
\hline Transport workers & $21.4 \%$ & $3.0 \%$ \\
\hline Agricultural workers & $13.0 \%$ & $3.5 \%$ \\
\hline "Immigrant occupations" as a whole & $13.6 \%$ & $53.9 \%$ \\
\hline Other occupations & $3.0 \%$ & $46.1 \%$ \\
\hline \multicolumn{3}{|l|}{ Female } \\
\hline Domestic workers & $38.4 \%$ & $41.9 \%$ \\
\hline Housekeeping and restaurant services workers & $10.6 \%$ & $9.9 \%$ \\
\hline Personal care and related workers & $11.0 \%$ & $7.0 \%$ \\
\hline Building cleaners & $10.0 \%$ & $2.2 \%$ \\
\hline "Immigrant occupations" as a whole & $21.1 \%$ & $61.0 \%$ \\
\hline Other occupations & $2.0 \%$ & $39 \%$ \\
\hline
\end{tabular}

Source: Our elaboration on Eurostat Italian LFS. 
Table 3 Foreign employment by country of origin (in thousands and \%)

\begin{tabular}{lrrrrrr}
\hline MALE & 2005 & 2008 & 2013 & 2005 & 2008 & 2013 \\
\hline Nationality & & & & & & \\
NMS13 & 96 & 218 & 340 & $14 \%$ & $21 \%$ & $27 \%$ \\
Other Europe & 204 & 256 & 299 & $29 \%$ & $25 \%$ & $24 \%$ \\
Africa & 227 & 277 & 267 & $32 \%$ & $27 \%$ & $21 \%$ \\
Asia and America & 181 & 275 & 364 & $26 \%$ & $27 \%$ & $29 \%$ \\
Total & 708 & 1027 & 1270 & $100 \%$ & $100 \%$ & $100 \%$ \\
\hline FEMALE & 2005 & 2008 & 2013 & 2005 & 2008 & 2013 \\
\hline Nationality & & & & & & \\
NMS13 & 96 & 205 & 405 & $23 \%$ & $30 \%$ & $38 \%$ \\
Other Europe & 120 & 196 & 298 & $29 \%$ & $29 \%$ & $28 \%$ \\
Africa & 62 & 74 & 73 & $15 \%$ & $11 \%$ & $7 \%$ \\
Asia and America & 135 & 209 & 287 & $33 \%$ & $31 \%$ & $27 \%$ \\
Total & 413 & 685 & 1063 & $100 \%$ & $100 \%$ & $100 \%$ \\
\hline
\end{tabular}

Source: Our elaboration on Eurostat Italian LFS.

Table 4 Flows of new residence permits issued every year, by reason (in thousands and \%)

\begin{tabular}{|c|c|c|c|c|c|c|c|c|c|c|c|}
\hline MALE & Work & Family & Study & $\begin{array}{r}\text { Asylum } \\
\text { seekers }\end{array}$ & Other & Total & Work & Family & Study & $\begin{array}{r}\text { Asylum } \\
\text { seekers }\end{array}$ & Other \\
\hline 2007 & 86 & 30 & 6 & 8 & 5 & 135 & $64 \%$ & $22 \%$ & $4 \%$ & $6 \%$ & $3 \%$ \\
\hline 2008 & 83 & 39 & 6 & 16 & 4 & 148 & $56 \%$ & $26 \%$ & $4 \%$ & $11 \%$ & $3 \%$ \\
\hline 2009 & 132 & 41 & 8 & 6 & 4 & 190 & $69 \%$ & $22 \%$ & $4 \%$ & $3 \%$ & $2 \%$ \\
\hline 2010 & 200 & 72 & 12 & 8 & 13 & 304 & $66 \%$ & $24 \%$ & $4 \%$ & $3 \%$ & $4 \%$ \\
\hline 2011 & 83 & 56 & 13 & 38 & 11 & 202 & $41 \%$ & $28 \%$ & $7 \%$ & $19 \%$ & $5 \%$ \\
\hline 2012 & 46 & 46 & 13 & 20 & 11 & 135 & $34 \%$ & $34 \%$ & $9 \%$ & $14 \%$ & $8 \%$ \\
\hline 2013 & 56 & 40 & 11 & 16 & 10 & 134 & $42 \%$ & $30 \%$ & $8 \%$ & $12 \%$ & $7 \%$ \\
\hline \multicolumn{12}{|c|}{ FEMALE } \\
\hline 2007 & 64 & 57 & 6 & 2 & 5 & 133 & $48 \%$ & $43 \%$ & $4 \%$ & $1 \%$ & $4 \%$ \\
\hline 2008 & 62 & 63 & 6 & 3 & 5 & 138 & $45 \%$ & $45 \%$ & $4 \%$ & $2 \%$ & $3 \%$ \\
\hline 2009 & 119 & 70 & 8 & 1 & 4 & 203 & $59 \%$ & $34 \%$ & $4 \%$ & $1 \%$ & $2 \%$ \\
\hline 2010 & 159 & 107 & 15 & 3 & 11 & 294 & $54 \%$ & $36 \%$ & $5 \%$ & $1 \%$ & $4 \%$ \\
\hline 2011 & 41 & 84 & 18 & 5 & 11 & 160 & $26 \%$ & $53 \%$ & $11 \%$ & $3 \%$ & $7 \%$ \\
\hline 2012 & 25 & 71 & 18 & 3 & 11 & 129 & $19 \%$ & $55 \%$ & $14 \%$ & $3 \%$ & $9 \%$ \\
\hline 2013 & 28 & 65 & 16 & 3 & 9 & 122 & $23 \%$ & $53 \%$ & $13 \%$ & $3 \%$ & $8 \%$ \\
\hline
\end{tabular}

Source: Istat. 
Table 5 Characteristics and dynamics in "migrant occupations"

\begin{tabular}{|c|c|c|c|c|}
\hline & \multicolumn{2}{|c|}{ Male } & \multicolumn{2}{|c|}{ Female } \\
\hline & 2005 & 2013 & 2005 & 2013 \\
\hline Foreigners Absorption in MigOcc. & $54 \%$ & $48 \%$ & $61 \%$ & $70 \%$ \\
\hline Natives Absorption in MigOcc. & $19 \%$ & $14 \%$ & $11 \%$ & $13 \%$ \\
\hline Foreign incidence in MigOcc. & $14 \%$ & $26 \%$ & $21 \%$ & $35 \%$ \\
\hline Foreign incidence in the Italian economy & $5 \%$ & $10 \%$ & $4.5 \%$ & $11 \%$ \\
\hline & $\begin{array}{c}\Delta 2005- \\
2008\end{array}$ & $\begin{array}{c}\Delta 2008- \\
2013\end{array}$ & $\begin{array}{c}\Delta 2005- \\
2008\end{array}$ & $\begin{array}{c}\Delta 2008- \\
2013\end{array}$ \\
\hline Foreign Employment growth in MigOcc. & $43 \%$ & $12 \%$ & $76 \%$ & $68 \%$ \\
\hline Foreign Employment growth in Non-MigOcc. & $48 \%$ & $37 \%$ & $51 \%$ & $32 \%$ \\
\hline Native Employment growth in MigOcc. & $-6 \%$ & $-25 \%$ & $7 \%$ & $13 \%$ \\
\hline Native Employment growth in Non-MigOcc. & $1 \%$ & $-6 \%$ & $2 \%$ & $-6 \%$ \\
\hline
\end{tabular}

Source: Our elaboration on Eurostat Italian LFS.

Table 6 Employment characteristics in migrant and non-migrant occupation for foreign workers

\begin{tabular}{lrr|rr}
\hline & \multicolumn{2}{c|}{ Male migrants } & \multicolumn{2}{c}{ Female migrants } \\
\cline { 2 - 5 } & MigOcc & Non-MigOcc & MigOcc & Non-MigOcc \\
\hline Share of low educated in 2008 & $58 \%$ & $47 \%$ & $41 \%$ & $34 \%$ \\
Share of low educated in 2013 & $58 \%$ & $46 \%$ & $39 \%$ & $36 \%$ \\
\hline Average no. of hours worked in 2008 & 40.2 & 41.5 & 31.5 & 36.4 \\
Average no. of hours worked in 2013 & 37.5 & 39.4 & 29.9 & 35.5 \\
\hline Share of part time in 2008 & $7 \%$ & $6 \%$ & $47 \%$ & $22 \%$ \\
Share of part time in 2013 & $15 \%$ & $13 \%$ & $53 \%$ & $28 \%$ \\
\hline Share of temporary workers in 2008 & $15 \%$ & $15 \%$ & $10 \%$ & $27 \%$ \\
Share of temporary workers in 2013 & $18 \%$ & $16 \%$ & $8 \%$ & $28 \%$ \\
\hline
\end{tabular}

Source: Our elaboration on Eurostat Italian LFS.

Table 7 Average marginal effects on the probability of having a monthly wage equal to or below the third decile, by year, country of origin, and gender

\begin{tabular}{|c|c|c|c|c|c|}
\hline & \multicolumn{2}{|c|}{ Migrant Occupations } & \multicolumn{2}{|c|}{ Non-Migrant Occupations } & \multirow[b]{2}{*}{$\begin{array}{r}\text { Natives in } \\
\text { MigOcc. }\end{array}$} \\
\hline Male & $\begin{array}{r}\text { New member } \\
\text { states }\end{array}$ & $\begin{array}{r}\text { Third country } \\
\text { nationals }\end{array}$ & $\begin{array}{r}\text { New member } \\
\text { states }\end{array}$ & $\begin{array}{r}\text { Third country } \\
\text { nationals }\end{array}$ & \\
\hline 2009 & $11.2 \%$ & $14.8 \%$ & $6.9 \%$ & $12.1 \%$ & $7.3 \%$ \\
\hline 2013 & $14.2 \%$ & $18.0 \%$ & $10.0 \%$ & $13.6 \%$ & $6.3 \%$ \\
\hline \multicolumn{6}{|l|}{ Female } \\
\hline 2009 & $20.6 \%$ & $20.5 \%$ & $14.6 \%$ & $8.1 \%$ & $18.5 \%$ \\
\hline 2013 & $21.8 \%$ & $20.1 \%$ & $6.4 \%$ & $8.8 \%$ & $19.0 \%$ \\
\hline
\end{tabular}

Source: Our elaboration on Eurostat Italian LFS. 
Figure 1: GDP and foreign employment growth rates in some EU countries 2004-2014

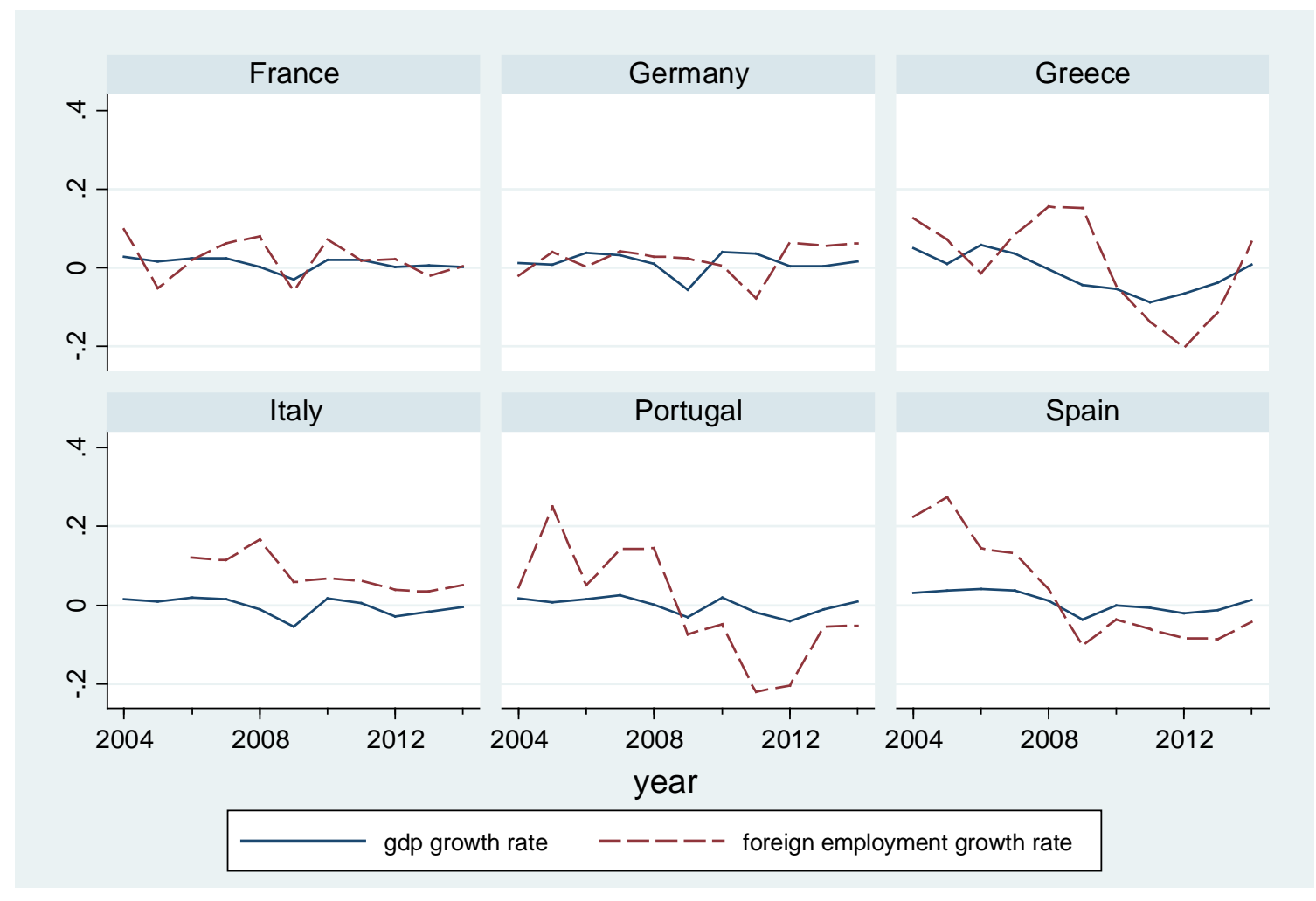

Source: Eurostat Italian LFS (foreign employment) and OECD data (GDP).

Note: Foreign employment refers to EU and third country nationals. 
Figure 2: Labour market indicators by nationality and gender

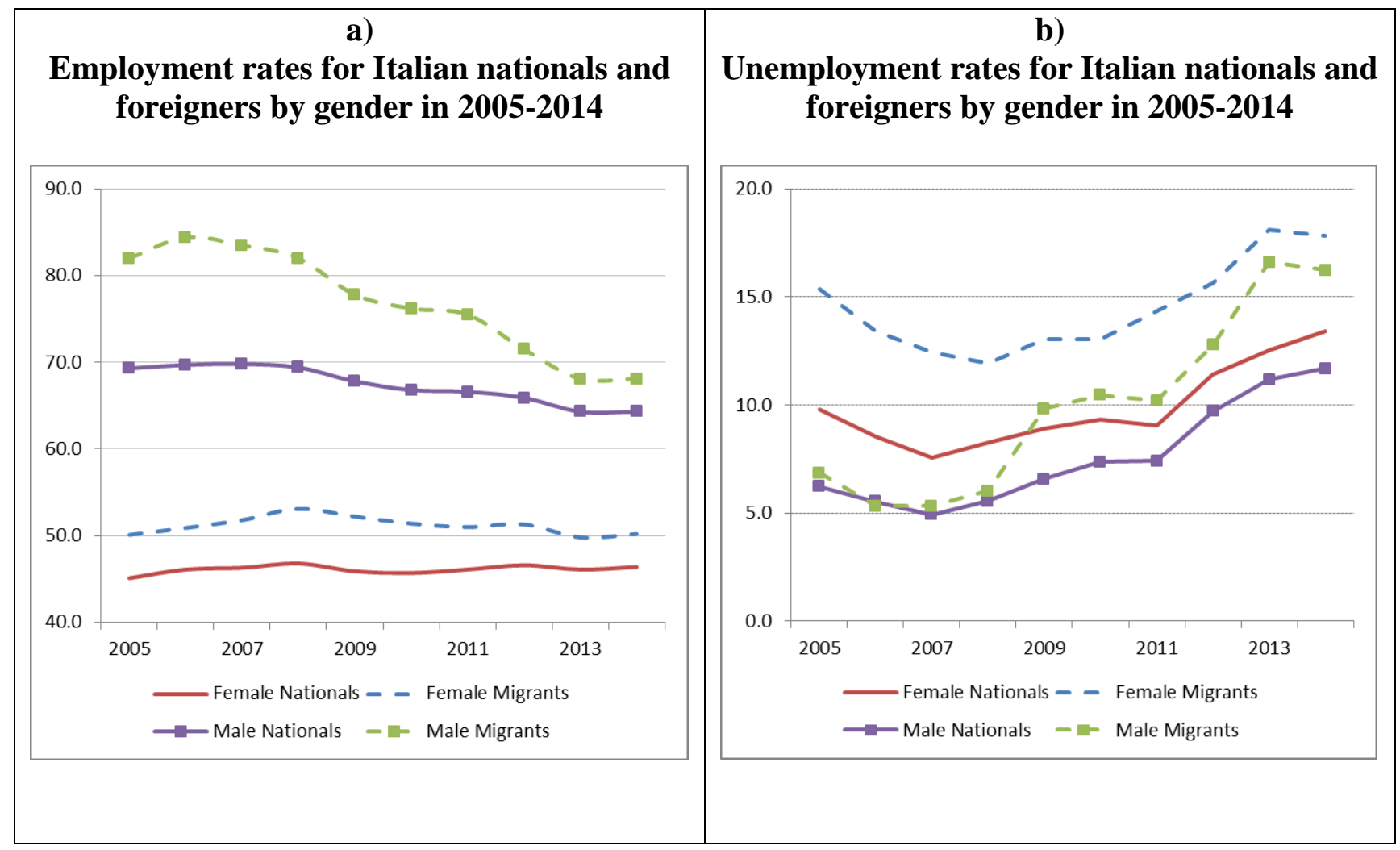

Source: Our elaboration on Eurostat Italian LFS. 
Figure 3. Average marginal effects on the probability of having a monthly wage equal to or below the third decile, by year and gender

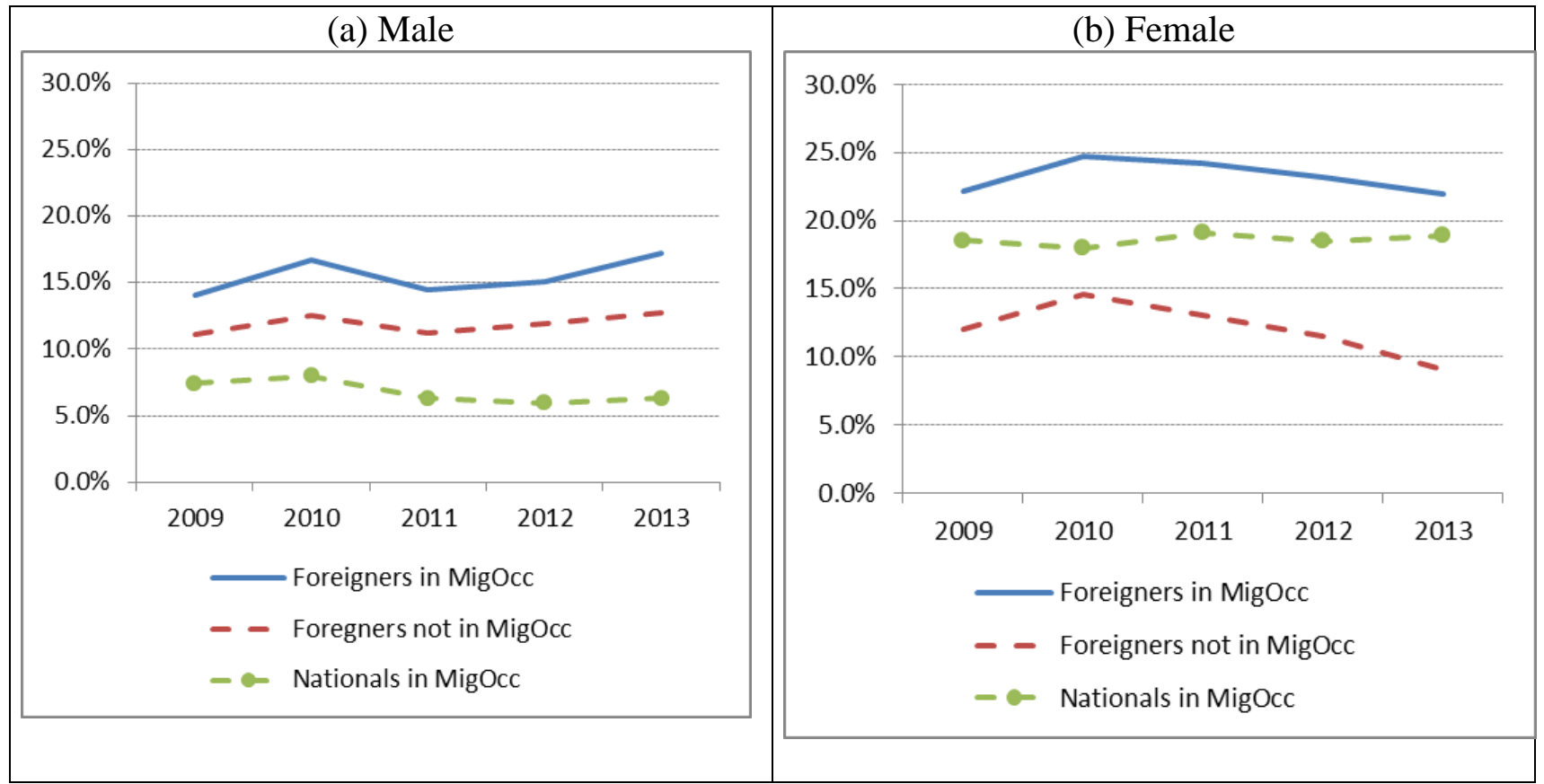

Source: Our elaboration on Eurostat Italian LFS.

Note: Average marginal effects of the probability of having a monthly wage below or equal the third decile of the wage distribution. Reference category= natives in non-migrant occupations. All the estimates have $p<0.001$. 


\section{References}

Ambrosini, M. 2001. La fatica di integrarsi. Immigrati e lavoro in Italia. Bologna: Il Mulino.

Bertoli, S., H. Brücker, and J. Fernández-Huertas Moraga. 2016 “The European Crisis and Migration to Germany,” Regional Science and Urban Economics 60: 61-72.

Bettio, F.M., C. Corsi, A. Dippoliti, A. Lyberaki, M. Lodovici, and A. Verashchagina. 2012. The Impact of the Economic Crisis on the Situation of Women and Men and on Gender Equality Policies. Brussels: European Commission, DG Justice.

Bonifazi, C. and C. Marini. 2013. "The Impact of the Economic Crisis on Foreigners in the Italian Labour Market”. Journal of Ethnic and Migration Studies 40 (3): 1-19.

Chiswick, B.R. and P.W. Miller 2009. "Earnings and Occupational Attainment among Immigrants" Industrial Relations 48 (3): 454-465

Christofides, L.M.M., A. Polycarpou, and K. Vrachimis. 2013. “Gender Gaps, 'Sticky Floors’ and ‘Glass Ceilings’ in Europe.” Labour Economics 21: 86-102.

Cvajner, M. and G. Sciortino. 2009. "Dal Mediterraneo al Baltico? Il cambiamento nei sistemi migratori italiani." iIn La fatica di cambiare. Rapporto sulla società italiana, edited by R. Catanzaro and G. Sciortino, 23-53. Bologna: Il Mulino .

Del Boca, D. and A. Venturini. 2015. “Migration in Italy is Backing the Old Age Welfare.” In Labor Migration, EU Enlargement, and the Great Recession, edited by K. Zimmermann and M. Kaneck. 59-83. Springer Verlag. doi: 10.1007/978-3-662-45320-9.

Dell’Aringa, C., C. Lucifora and L. Pagani. 2015. “Earnings Differentials Between Immigrants and Natives: The Role of Occupational Attainment.” IZA Journal of Migration 4: 8.

Dolado, J.J. 2016. “EU Dual Labour Markets: Consequences and Potential Reforms.” In Economics without Borders: Economic Research for European Policy Challenges, edited by R. Blundell et al. 74-112. Cambridge: Cambridge University Press.

Dustmann, C. and T. Frattini. 2011. “Immigration: The European Experience,” IZA Discussion Paper 6261.

Finotelli, C. and G. Sciortino. 2013. "Through the Gates of the Fortress: European Visa Policies and the Limits of Immigration Control.” Perspectives on European Politics and Society 14 (1): 80-101.

Finotelli C. and I. Ponzo, 2017, Integration in times of economic decline. Migrant inclusion in Southern European societies: trends and theoretical implications Journal of Ethnic and Migration Studies, 
Gavosto, A., A. Venturini, and C. Villosio. 1999. “Do Immigrants Compete with Natives?” Labour 13: 603-622.

Goos, M., A. Manning, and A. Salomons. 2009. “Job Polarization in Europe.” The American Economic Review (99) 2: 58-63.

Hatton, T.J. and J. G., Williamson 2009. “Global Economic Slumps and Migration.” http://voxeu.org/article/global-economic-slumps-and-migration.

ISTAT. 2014. Indagine sulle forze di lavoro. Roma: ISTAT.

Kahanec, M., A. Zaiceva, and K. F. Zimmermann. 2009. “Lessons from Migration after EU Enlargement.” In EU Labor Markets After Post-Enlargement Migration, edited by M. Kahanec and K. F. Zimmermann, 3-45. Berlin: Springer.

Kahanec, M. and K. F. Zimmermann. 2016. Labour Migration, EU Enlargement, and the Great Recession. Berlin: Springer.

Koser, K. 2009. The Impact of Financial Crises on International Migration: Lessons Learned. International Organization for Migration, IOM, DP 37.

Lewis, E. 2011. “Immigration, Skill Mix, and Capital Skill Complementarity.” Quarterly Journal of Economics 126 (2): 1029-1069. doi: 10.1093/qje/qjr011.

Marchetti, S. and A. Venturini. 2013. "Mothers and Grandmothers on the Move: Labour Mobility and the Household Strategies of Moldovan and Ukrainian Migrant Women in Italy.” International Migration 52 (5): 111-126.

Murat, M. and S. Paba, 2003. “International Migration, Outsourcing and Italian Industrial Districts.” Proceedings of the Conference on "Clusters, Industrial Districts and Firms: The Challenge of Globalization.” Modena, Italy. 12-13 September.

Olivetti, C. and B. Petrongolo. 2008. “Unequal Pay or Unequal Employment? A Cross Country Analysis of Gender Gaps.” Journal of Labour Economics 26: 621-654.

OECD. 2014a. International Migration Outlook. Paris: OECD Publishing.

OECD. 2014b. Jobs for Immigrants (Vol. 4). Labour Market Integration in Italy. Paris: OECD Publishing.

Paggiaro, A., 2013. “How Do Immigrants Fare During the Downturn? Evidence from Matching Comparable Natives.” Demographic Rresearch. 28 (8): 229-258.

Papademetriou, D.G., M. Sumption, A. Terrazas, C. Burkert, S. Loyal, and R. Ferrero-Turrión. 2010. Migration and Immigrants Two Years after the Financial Collapse: Where Do We Stand? Washington, DC: Migration Policy Institute. 
Paserman, M.D. 2013. “Do High-Skill Immigrants Raise Productivity? Evidence from Israeli Manufacturing Firms, 1990-1999.” IZA Journal of Migration, 2:6. Springer. DOI: 10.1186/2193-9039-2-6

Pastore, F., E. Salis, and C. Villosio, 2013. “L’Italia e l’immigrazione “low cost”: fine di un ciclo?” Mondi Migranti, 1/2013 (19).

Recchi, E. 2015. Mobile Europe: Theory and Practice of Free Movement in the EU. Basingstoke: Palgrave MacMillan.

Reyneri, E. 2004. “Immigrants in a Segmented and Often Undeclared Labour Market.” Journal of Modern Italian Studies 9 (1): 71-93.

Reyneri, E. 2009. "Migration and the Economic Crisis in Western Europe.” Paper presented at the 6th Congress on Migration in Spain, Coruña, 17-19 September.

Reyneri, E., and G. Fullin. 2008. “New Immigration and Labour Markets in Western Europe: A Trade-off Between Unemployment and Job Quality”. Transfer. European Review of Labour and Research 4 (4): 573-588.

Reyneri, E. and G. Fullin, 2011. "Low Unemployment and Bad Jobs for New Immigrants in Italy.” International Migration 49 (1): 118-147.

Salamonska, J. and E. Recchi. 2016. "Europe Between Mobility and Sedentarism: Patterns of Cross-Border Practices and their Consequences for European Identification.” Florence. Migration Policy Centre WP: 2016/50.

Schumpeter, J. A. 1934. "Depressions: Can We Learn from Past Experience?" in The Economics of the Recovery Program edited by J. A. Schumpeter et al. 3-21. New York, London: McGrawHill.

Staffolani, S. and F. Valentini, 2010. "Does Immigration Raise Blue and White Collar Wages of Natives? The case of Italy.” Labour 24 (3): 295-310.

Strom S., A. Venturini, and C.Villosio. 2013. "Wage Assimilation: Migrants versus Natives, Internal Migrants versus Foreign Migrants,” Florence. Migration Policy Centre Working Paper 2013/30.

Trenz H.-J., and Triandafyllidou A. 2016: Complex and dynamic integration processes in Europe: intra EU mobility and international migration in times of recession, Journal of Ethnic and Migration Studies,43(4).

Venturini, A. and C. Villosio. 2006. "Labour Market Effects of Immigration into Italy: An Empirical Analysis.” International Labour Review 145: 91-118.

Zanfrini, L. 2015. The Diversity Value: How to Reinvent the European Approach to Immigration, Maidenhead, UK: McGraw-Hill Education. 